\title{
Multitemporal analysis of estimated soil loss for the river Mourão watershed, Paraná - Brazil
}

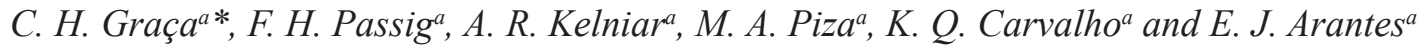 \\ aNúcleo de Pesquisa em Engenharia Ambiental, Universidade Tecnológica Federal do Paraná - UTFPR, \\ Via Rosalina Maria dos Santos 1233, CEP 87301-899, Campo Mourão, PR, Brazil \\ *e-mail: henriquechg@gmail.com
}

Received: January 17, 2015 - Accepted: May 20, 2015 - Distributed: November 30, 2015

(With 10 figures)

\begin{abstract}
The multitemporal behavior of soil loss by surface water erosion in the hydrographic basin of the river Mourão in the center-western region of the Paraná state, Brazil, is analyzed. Forecast was based on the application of the Universal Soil Loss Equation (USLE) with the data integration and estimates within an Geography Information System (GIS) environment. Results had shown high mean annual rain erosivity $\left(10,000 \mathrm{MJ} \cdot \mathrm{mm} \cdot \mathrm{ha}^{-1} \cdot \mathrm{h}^{-1} \cdot \mathrm{year}{ }^{-1}\right)$, with great concentration in January and December. As a rule, soils have average erodibilities, exception of Dystroferric Red Latisol (low class) and Dystrophic Red Argisol (high class). Although the topographic factor was high $(>20)$, rates lower than 1 were predominant. Main land uses comprise temporal crops and pasture throughout the years. The watershed showed a natural potential for low surface erosion. When related to usage types, yearly soil loss was also low $\left(<50\right.$ ton.ha ${ }^{-1}$.year $\left.{ }^{-1}\right)$, with more critical scores that reach rates higher than 150 ton.ha ${ }^{-1}$.year ${ }^{-1}$. Soil loss over the years did not provide great distinctions in distribution standards, although it becames rather intensified in some sectors, especially in the center-eastern and southwestern sections of the watershed.
\end{abstract}

Keywords: soil loss, USLE, GIS, river Mourão watershed.

\section{Análise multitemporal da perda de solo estimada para a bacia hidrográfica do rio Mourão, Paraná - Brasil}

\section{Resumo}

Este estudo visa analisar o comportamento multitemporal da perda de solo por erosão hídrica laminar na bacia hidrográfica do rio Mourão, localizada na região centro-ocidental do Estado do Paraná - Brasil. A predição foi baseada na aplicação da Equação Universal de Perdas de Solo (USLE), com integração dos dados e estimativas realizados em ambiente SIG (Sistema de Informações Geográficas). Os resultados mostram elevada erosividade da chuva média anual (10.000 MJ.mm.ha $\left.{ }^{-1} \cdot \mathrm{h}^{-1} \cdot \mathrm{ano}^{-1}\right)$. Os solos apresentam, em geral, média erodibilidade, com exceções do Latossolo Vermelho Distroférrico (classe baixa) e o Argissolo Vermelho Distrófico (classe alta). O fator topográfico atingiu índices elevados $(>20)$, no entanto, predominaram os valores inferiores a 1. Os tipos de usos principais são as lavouras temporárias e pastagem, para todos os anos. A bacia apresentou Potencial Natural a Erosão laminar predominante baixo, quando relacionado aos tipos de usos resultou numa perda de solo anual estimada também baixa ( $<50$ ton.ha ${ }^{-1}$.ano $\left.{ }^{-1}\right)$, com pontos mais críticos que atingem valores superiores a 150 ton.ha ${ }^{-1} \cdot$ ano $^{-1}$. A perda de solo entre os anos não apresentou grandes distinções nos padrões de distribuição, apenas intensificou-se em alguns setores, como nas porções centroleste e sudoeste da bacia.

Palavras-chave: perda de solo, USLE, SIG, bacia do rio Mourão - PR.

\section{Introduction}

Soil degradation is one of the main social and environmental issues in Brazil, especially due to intensive and widespread agriculture in the country.

The urgent need to produce more food and the agricultural model applied during hundreds of years in tropical regions, soil intensive occupation (Primavesi, 1988), have contributed towards the deterioration of the environment (Castro and
Valério Filho, 1997), with significant soil loss in erosion processes (Valério Filho, 1994), mainly caused by diffused or concentrated rainwater runoff that slowly removes uniform surface horizons off the soil (Galerani et al., 1995). This type of erosion is highly effective in agricultural areas where soils during certain periods of the year are bare or unprotected and, therefore, prone to the erosion 
activities of heavy rain (Goldman et al., 1986; Silva and Schulz, 2002; Prado and Nóbrega, 2005).

The erosion process starts when rainfall triggers the disintegration of soil particles and the movement of all this material, with the exposure to the hydrodynamic activities of surface runoff (Resende and Almeida, 1985; Ramos, 1995; Guerra, 2010). Its highly complex causes, with diverse typologies and extensiveness, depend on the particularities of the different regions (Paes et al., 2010).

Erosion is generally aggravated by fast modifications on the vegetal cover and management type (Rodrigues, 1984), whilst its dynamics is related to human activities. Changes in natural conditions and non-controlled artificiality of the environment become the main factor which causes the intensification of the erosion process on agricultural land (Tomazoni et al., 2005).

The rates of soil loss and the identification of the main control factors that increase or delay such processes should be understood so that the local effects of soil erosion could be avoided (Rousseva, 2003; Gaspari et al., 2009; Zhang et al., 2009). Therefore, control and planning strategies for the adequate use of land are required, among which the application of empirical mathematical models within a computerized environment may be mentioned (Carvalho Junior and Guimarães, 2001). In fact, they estimate the loss of soil in a determined area caused by natural and human factors that most affect the development of the erosion process (Castro and Valério Filho, 1997; Silva et al., 2003; Moreti et al., 2003).

The Universal Soil Loss Equation (USLE), prepared by Wischmeier and Smith (1978), with later adaptations to local landscapes and conditions (Bertoni and Lombardi Neto, 2005) is one of the most employed worldwide, among other models. In fact, USLE provides the activities of the main factors that affect soil loss by water erosion, such as the erosivity of rainfalls (Rufino, 1986; Catâneo et al., 1992; Lombardi Neto and Moldenhauer, 1992; Albuquerque et al., 1994), soil erodibility (Lombardi Neto and Bertoni, 1975; Denardin, 1990; Guerra and Almeida, 1993), length of slope and declivity degree (Ranieri et al., 1998; Silva, 1999), soil characteristics and its use and management (Lopes, 1980; Gitas et al., 2009).

Current assay analyzes the multi temporal behavior of soil loss by surface water erosion in the watershed of the river Mourão in the Paraná state, Brazil, by Universal Soil Loss Equation (USLE) through simulations applied within a Geographic Information System (GIS) environment for 1985, 1993, 2003 and 2013. The above reference years were selected for the temporal interval of approximately ten years which, due to the real dynamics of the agricultural medium, expresses significant changes in different types of land use and management practices in the region. In other words, it may or may not reflect the intensification of erosion processes.

\section{Characteristics of the Area Under Analysis}

The hydrographic basin of the river Mourão is located between the coordinates $345,000 \mathrm{mE} 390,000 \mathrm{mE}$ and $7,300,000 \mathrm{mN}$ the $7,375,000 \mathrm{mN}$, within the center-western region of the state of Paraná, Brazil. It is an important affluent on the left margin of the river Ivaí, with approximately $1,648.21 \mathrm{~km}^{2}$ (Figure 1).

According to classification by Köppen (1948), the basin has a predominantly subtropical mesothermal wet climate (Cfa), with hot summers and rare frosts; concentration of rains during the summer months and no well-defined dry season. Mean temperatures of the hottest months of the year are above $26^{\circ} \mathrm{C}$ and mean temperatures for the coldest months are below $18^{\circ} \mathrm{C}$ (Caviglione et al., 2000). Mean yearly rainfall ranges between 1,500 and $1,900 \mathrm{~mm}$. Whereas December, January and February are the months with the heaviest rainfall with averages between 175 and $200 \mathrm{~mm}$, July and August are the driest months with mean rainfall ranging between 50 and $100 \mathrm{~mm}$ (Andrade and Nery, 2002; Baldo, 2006).

The rocky substrate mainly belongs to the Brazilian Mountain Range Formation with rocks related to the basalt trap, characterized by basic amygdaloidal basalt, compact basalt, amygdaloidal basalt, vesicular ballast and basaltic or/and sedimentary cleft (MINEROPAR, 2001). In a smaller proportion, the Caiuá Formation comprises eolic sandstones with enormous crossed stratifications and underwater deposits or temporal lakes developed among dunes characterized by parallel horizontal stratifications (Bigarella and Mazuchowski, 1985) and also recent small spots of sedimentary deposits (MINEROPAR, 2001).

Land relief is characterized by planed hilltops, rectilinear slopes and concave bases, with valley beds (the Campo Mourão Plateau) and long isolated hilltops, convex and concave-convex slops with open U-shaped valleys (High and Medium Piquiri Plateau) (Santos et al., 2006). The height of the water shed lies between 283 and $855 \mathrm{~m}$, with an altimeter gradient of $572 \mathrm{~m}$, featuring a predominance of less than $8 \%$ declivity classes, even though the presence of $8-20 \%$ classes on the center-eastern section of the watershed are significant.

Soil classes are associated to types of land relief and geological layers. Red Latisols (Dystroferric, Dystrophic and Eutrophic, clayey) may be found on the top and on the high slopes; Red Argisols (Dystrophic and Eutrophic, average/sandy) may be found in the mid-low slopes on the sandstones of the Caiuá Arenite Formation; Red Nitosols (Eutroferric and Dysferric, clayey) may be found on the basalts of the Mountain Range Formation. LitholicNeosols (eutrophic, clayey) are associated with more dissected reliefs.

Vegetation is a remnant of the Semidecidual Seasonal Forest (Mountain and sub-mountain), Mixed Forest (mountain) and Savannah Forest (Savannah) (Paraná, 1987). Owing to crop extraction and exploitation of land throughout the years, only few patches of land with the original vegetation are still extant. Temporary cash crops (sugarcane, soybean, corn and wheat) predominate in the region. These crops actually constitute the local economy.

\section{Material and Methods}

The mathematic model by Wischmeier and Smith (1978) to calculate soil loss by erosion is given as a function of natural variables $(\mathrm{R}, \mathrm{K}, \mathrm{L}, \mathrm{S})$ that simulate the natural 


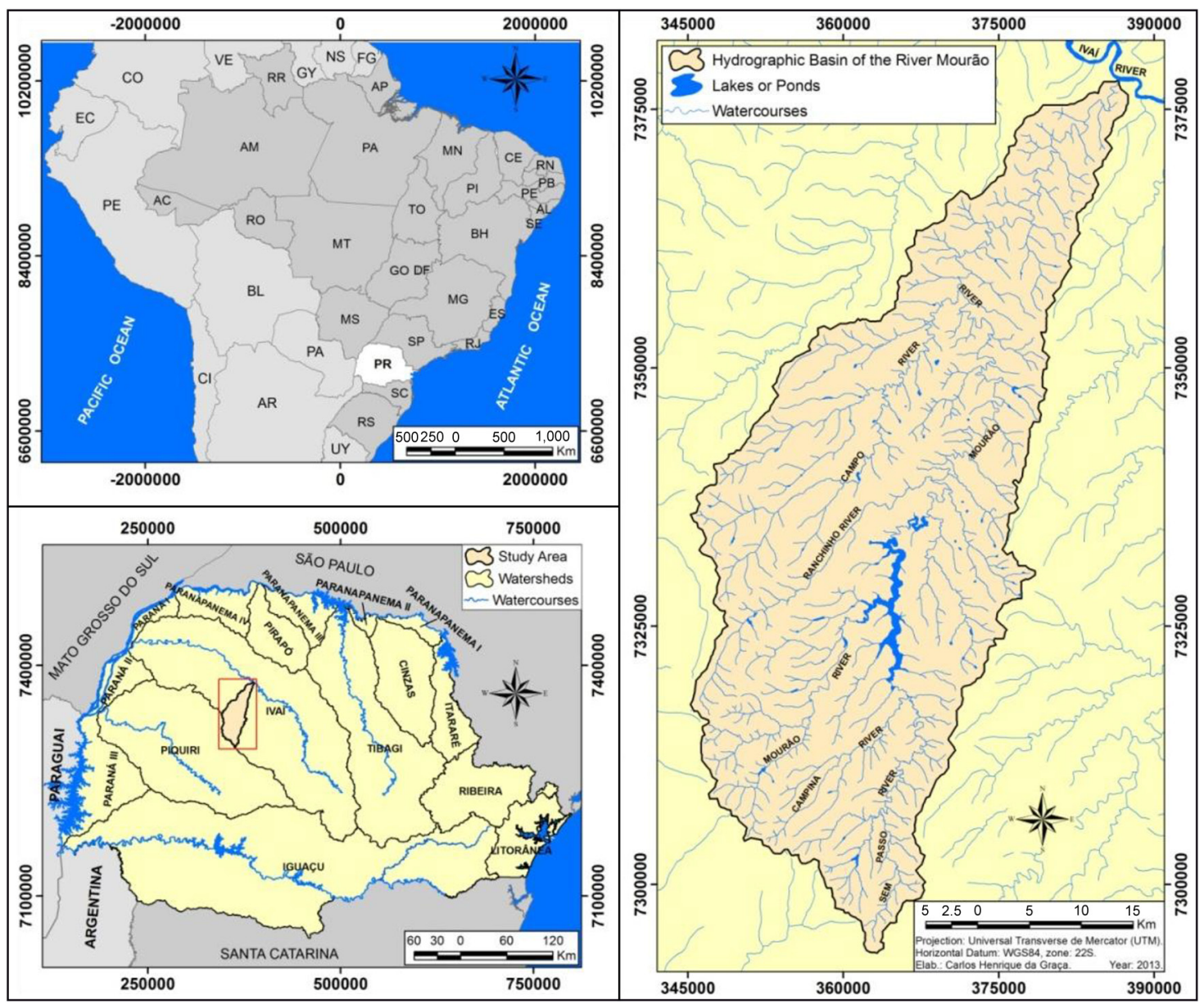

Figure 1. Area under analysis.

potential for surface erosion (Pedro and Lorandi, 2004) and anthropic variables ( $\mathrm{C}$ and $\mathrm{P}$ ) that represent land use conditions. All these factors provide simulated soil loss by the Equation 1:

$$
A=\text { R.K.L.S.C.P }
$$

Where $\mathrm{A}=$ soil loss $\left(\mathrm{t} \cdot \mathrm{ha}^{-1} \cdot \mathrm{year}^{-1}\right) ; \mathrm{R}=$ erosivity factor of rainfall $\left(\mathrm{MJ} \cdot \mathrm{mm} \cdot \mathrm{ha}^{-1} \cdot \mathrm{h}^{-1}\right.$.year $\left.{ }^{-1}\right) ; \mathrm{K}=$ erodibility factor of the soil (t.h. $\left.\mathrm{MJ}^{-1} \cdot \mathrm{mm}^{-1}\right) ; \mathrm{L}=$ slope length (a-dimensional); $\mathrm{S}=$ declivity factor (a-dimensional); $\mathrm{C}=$ usage and management of soil (a-dimensional); $\mathrm{P}=$ conservation practices (a-dimensional).

Factor R (erosivity) was calculated with rainfall rates of the temporal series 1980-2013, at 13 collecting sites in the interior and in the neighborhood of the watershed, coordinated by the Instituto das Águas do Paraná (2014) (Table 1).

Calculations followed Rufino et al. (1993) who established eight iso-erosive regions for the state of Paraná, Brazil, and applied the equation $\mathrm{Y}=\mathrm{a}+\mathrm{b}(\mathrm{x})$ to determine the linear and angular coefficients of rain erosivity. The rates proper to the area under analysis may be found in the iso-erosion region $5(\mathrm{Y}=19.55+4.94 * \mathrm{x})$ according to rainfall data given by Equation 2:

$R=19.55+4.94\left(\frac{\mathrm{p}^{2}}{\mathrm{P}}\right)^{9.80665}$

Where $\mathrm{R}=$ Erosion Index of rainfall $\left(\mathrm{MJ} \cdot \mathrm{mm} \cdot \mathrm{ha}^{-1} \cdot \mathrm{h}^{-1} \cdot \mathrm{month}^{-1}\right)$; $\mathrm{p}=$ mean monthly rainfall $(\mathrm{mm}) ; \mathrm{P}=$ mean yearly rainfall $(\mathrm{mm}) ; 9.80665=$ Kgf.m conversion to $\mathrm{MJ}$.

The yearly indexes of the $\mathrm{R}$ factor were obtained by the sum of monthly rates and expressed in MJ.mm.ha ${ }^{-1} \cdot \mathrm{h}^{-1} \cdot \mathrm{year}^{-1}$, established in mean yearly erosivity, 33-year series.

Factor K (erodibility) rates were established by the identification of soil types in the hydrographic basin obtained from the Mapa de Solos do Estado do Paraná [Map of the Soils of the state of Paraná] - scale 1:250.000 (EMBRAPA, 2007). Since more detailed surveys and sample collections could not be made to determine local erodibility, the rates established for the state of São Paulo, Brazil, with similar characteristics as those in the watershed under analysis, were taken as reference from research by Bueno (1994), Lombardi Neto (1994), Cerri (1999), Burin (1999), Marcondes et al. (2002), complied by Silva and 
Table 1. Collection sites of rainfall data (UTM coordinates are in meters).

\begin{tabular}{cccc}
\hline Code ANEEL* & Longitude (E) & Latitude $(\mathbf{N})$ & Altitude (m) \\
\hline 02352002 & 379,494 & $7,365,576$ & 315 \\
02352029 & 364,000 & $7,355,011$ & 527 \\
02352030 & 374,092 & $7,345,843$ & 425 \\
02352033 & 364,196 & $7,367,286$ & 550 \\
02352034 & 372,642 & $7,369,239$ & 520 \\
02352061 & 377,950 & $7,387,679$ & 339 \\
02452014 & 346,065 & $7,313,605$ & 702 \\
02452029 & 335,187 & $7,334,804$ & 582 \\
02452035 & 342,867 & $7,296,956$ & 650 \\
02452041 & 373,998 & $7,289,794$ & 819 \\
02452044 & 377,891 & $7,298,473$ & 603 \\
02452045 & 357,600 & $7,319,079$ & 668 \\
02452046 & 371,442 & $7,313,858$ & 800 \\
\hline
\end{tabular}

*Agência Nacional de Energia Elétrica (National Agency of Electrical Energy) (Instituto das Águas do Paraná, 2014).

Alvares (2005) in a database on the erodibility of soils in the state of São Paulo.

Updating of the previous pedological classification, employed in current research, followed criteria of the Sistema Brasileiro de Classificação de Solos [Brazilian Soil Classification System] (EMBRAPA, 2013).

Topographic factor rates (LS) formed by adding slope length (L) and declivity (S) was calculated from Shuttle Radar Topography Mission (SRTM) images from the electronic site of the TOPODATA project (INPE, 2011) using the concept of contribution area (Desmet and Govers, 1996), widely used for the automatic calculation of the slope length (Andrade et al., 2002), by Equation 3:

$L_{i, j}=\frac{\left(A_{i, j-i n}+D^{2}\right)^{m+1}-\left(A_{i, j-i n}\right)^{m+1}}{D^{m+2} \cdot X_{i, j}^{m} \cdot(22,13)^{m}}$

Where: $\mathrm{A}_{\mathrm{i}, \mathrm{j}-\mathrm{in}}=$ area of contribution of the cell with coordinates $(\mathrm{i}, \mathrm{j})\left(\mathrm{m}^{2}\right) ; \mathrm{D}=$ size of cell $(\mathrm{m})$, or rather, pixel size $(30 \mathrm{~m})$; $\mathrm{m}=$ coefficient as a function of declivity for cell grade with coordinates $(i, j) ; x=$ coefficient as a function of the aspect for cell grade with coordinates $(i, j)$.

Following Andrade et al. (2002), Coefficient " $\mathrm{m}$ " is obtained by some declivity classes:

- $\mathrm{m}=0.5$ if declivity is $>5 \%$;

- $\mathrm{m}=0.4$ for interval between $3 \%$ and $5 \%$;

- $\mathrm{m}=0.3$ for interval between $1 \%$ to $3 \%$;

- $\mathrm{m}=0.2$ for declivity $<1 \%$.

Declivity was calculated by algorithm described by Zevenbergen and Thorne (1987), Equation 4:

$\mathrm{G}_{\mathrm{i}, \mathrm{j}}=\mathrm{G}_{\mathrm{x}}{ }^{2}+\mathrm{G}_{\mathrm{y}}{ }^{2}$

Where: $\mathrm{G}_{\mathrm{x}}=$ gradient for direction $\mathrm{x}(\mathrm{m} / \mathrm{m}) ; \mathrm{G}_{\mathrm{y}}=$ gradient for direction y $(\mathrm{m} / \mathrm{m})$.

Information on vegetal cover and land use in the watershed, highly relevant for the determination of the use and management of soil (C) and conservationist practices $(\mathrm{P})$, were obtained by visual interpretation and supervised classification (Maximum Likelihood Method) of images from LandSat 5 and 8 (sensor TM and TIRS), corresponding to orbit 223 and site 76 and 77, taken on $11 / 05 / 1985 ; 15 / 04 / 1993 ; 18 / 09 / 2003 ; 09 / 06 / 2013$, and obtained from the electronic site of the U.S Geological Survey (USGS-GLOVIS, 2013).

Rates applied for the use and management of soil (C) were based on research by Vázquez-Fernández et al. (1996), Vitte (1997), Tomazoni and Guimarães (2005) and Oliveira et al. (2007). Attributions of conservationist practice rates $(\mathrm{P})$ followed criteria by Bertoni and Lombardi Neto (2005), with contour planting as the main practice in the watershed.

The preparation of maps, directories and specific database Geographic Information System (GIS) for factors in USLE were performed with SAGA GIS (System for Automated Geoscientific Analyses) 2.0 and ArcGIS Desktop 10.1 (ESRI - Environmental Systems Research Institute), with automation of input data in AML (Arc Macro Language) (Longley et al., 2013). Output data were exported as raster and edited in the UTM projection system (zone 22 south), horizontal Datum WGS84 and scale 1: 250.000.

Data processing with regard to slope length $(\mathrm{L})$ and declivity (S) and topographic factor (LS), was developed by SAGA GIS from route Modules - Terrain Analysis Hydrology - Topography Indexes - LS factor.

Data on erosivity $(\mathrm{R})$, erodibility $(\mathrm{K})$, use and management of soil $(\mathrm{C})$, conservationist practices $(\mathrm{P})$ and the integration of data that constitute USLE were performed in ArcMap (ArcGIS), with routes applied at extension ArcToolBoxSpatial Analyst Tools: Interpolation - Kriging (erosivity); Multivariate-Maximum Likelihood Classification (vegetal cover and land use); Reclass - Reclassify. The latter was used to attribute indexes of the factors (R, K, LS, C and P) for raster images. The route Map Algebra: Raster Calculator was employed to calculate and detail soil loss rates.

Statistical treatments (mean, deviation standard, coefficient of variation, coefficient of co-relation, estimated error) 
and graphs were prepared on the electronic spreadsheet of Excel (Microsoft Corporation) 2007.

\section{Results and Discussions}

Erosivity rates (factor R) for the watershed may be considered very high, according to classification by Carvalho (2008), with an annual mean of approximately $10,000 \mathrm{MJ} \cdot \mathrm{mm} \cdot \mathrm{ha}^{-1} \cdot \mathrm{h}^{-1} \cdot \mathrm{year}^{-1}$. They agree with rates by Waltrick et al. (2011) for the central region of the state of Paraná.

Indexes range between 9,000 MJ.mm.ha ${ }^{-1} \cdot \mathrm{h}^{-1} \cdot$ year $^{-1}$ and slightly over $10,250 \mathrm{MJ} \cdot \mathrm{mm} \cdot \mathrm{ha}^{-1} \cdot \mathrm{h}^{-1} \cdot \mathrm{year}^{-1}$, with a well-defined decreasing distribution pattern upstream to downstream of the hydrographic basin (Figure 2), with an approximate amplitude of 1,250 MJ.mm.ha ${ }^{-1} \cdot \mathrm{h}^{-1} \cdot \mathrm{year}^{-1}$.

Mean annual standard deviation (714.948 MJ.mm. $\mathrm{ha}^{-1} \cdot \mathrm{h}^{-1} \cdot$ year $^{-1}$ ) enhanced a significant interannual variability between the erosivity rates which directly affected the intensification of the erosion processes when they were not regularly monitored. Mean yearly estimate error

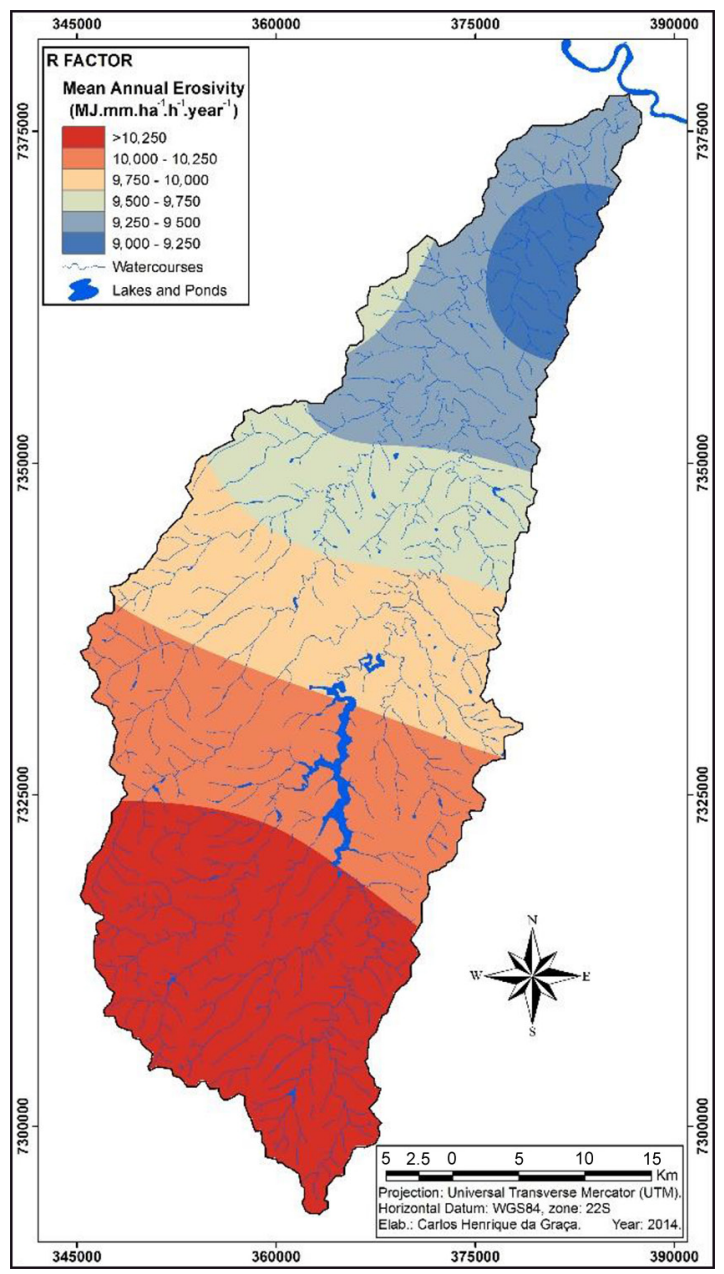

Figure 2. Mean yearly erosivity for the river Mourão watershed, state of Paraná - Brazil.
(198.29 MJ.mm.ha ${ }^{-1} \cdot \mathrm{h}^{-1}$.year ${ }^{-1}$ ) was relatively low when the great amount of data and years under analysis were taken into account. The same occurred with the coefficient of variation $( \pm 7.08 \%)$.

Mean monthly erosivity tended to concentrate high indexes in January and December, both months with rates above 1,200 MJ.mm.ha ${ }^{-1} \cdot \mathrm{h}^{-1} \cdot \mathrm{month}^{-1}$, followed by October $\left(1,165.76 \mathrm{MJ} \cdot \mathrm{mm} \cdot \mathrm{ha}^{-1} \cdot \mathrm{h}^{-1} \cdot \mathrm{month}^{-1}\right)$, February (1,087.97 MJ.mm. $\left.\mathrm{ha}^{-1} \cdot \mathrm{h}^{-1} \cdot \mathrm{month}^{-1}\right)$ and May $\left(1,000 \cdot 47 \mathrm{MJ} \cdot \mathrm{mm} \cdot \mathrm{ha}^{-1} \cdot \mathrm{h}^{-1} \cdot \mathrm{month}^{-1}\right)$. Although the highest indexes may be pinpointed in January and December, concern is due to October and May with regard to erosion and soil loss potential by surface runoff. These months represent the between-harvest period in the region for the agricultural zoning of the state of Paraná (Caramori et al., 2003). Soils lie unprotected with potential erosion of rains. Lowest indexes are concentrated in August and July, with low indexes of $350 \mathrm{MJ} \cdot \mathrm{mm} \cdot \mathrm{ha}^{-1} \cdot \mathrm{h}^{-1} \cdot \mathrm{month}^{-1}$ (Figure 3).

The soils of the river Mourão hydrographic basin have, as a rule, average erodibility, with the exception of Red Dystroferric Latisol and Red Dystrophic Argisol, respectively with low and high erodibility class, according to classification by Carvalho (2008).

Latisols are the least erodible (Table 2). In fact, they are developed, well-structured deep soils, located at the top and on the segments of high to average slopes (Figure 4).

Table 2. Erodibility rates attributed to soil types of the hydrographic basin of the river Mourão, state of Paraná Brazil.

\begin{tabular}{lc}
\hline \multicolumn{1}{c}{$\begin{array}{c}\text { Soils Types } \\
\text { (EMBRAPA, 2007) }\end{array}$} & $\begin{array}{c}\text { Value of K } \\
\text { (t.h.MJ-1. } \mathbf{m m}^{-\mathbf{1}} \text { ) }\end{array}$ \\
\hline Dystrophic Red Argisol & $0.0350^{1}$ \\
Eutrophic Red Argisol & $0.0280^{1}$ \\
Dystroferic Red Latosol & $0.0128^{2}$ \\
Dystrophic Red Latosol & $0.0175^{1}$ \\
Eutropheric Red Latosol & $0.0098^{2}$ \\
Eutrophic Litholic Neosol & $0.0250^{3}$ \\
Eutroferric Red Nitosol & $0.0180^{4}$ \\
Dystroferric Red Nitosol & $0.0174^{5}$ \\
\hline Source: &
\end{tabular}

Source: ${ }^{1}$ Marcondes et al. (2002). ${ }^{2}$ Lombardi Neto (1994). ${ }^{3}$ Bueno (1994). ${ }^{4}$ Burin (1999). ${ }^{5}$ Cerri (1999).

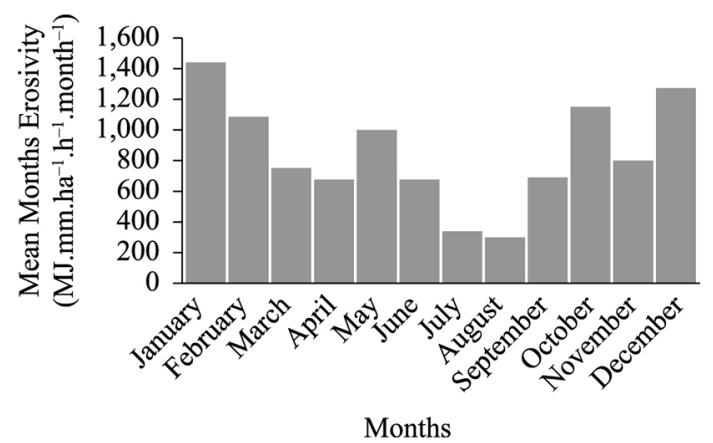

Figure 3. Distribution of mean monthly erosivity for the river Mourão watershed, state of Paraná - Brazil. 


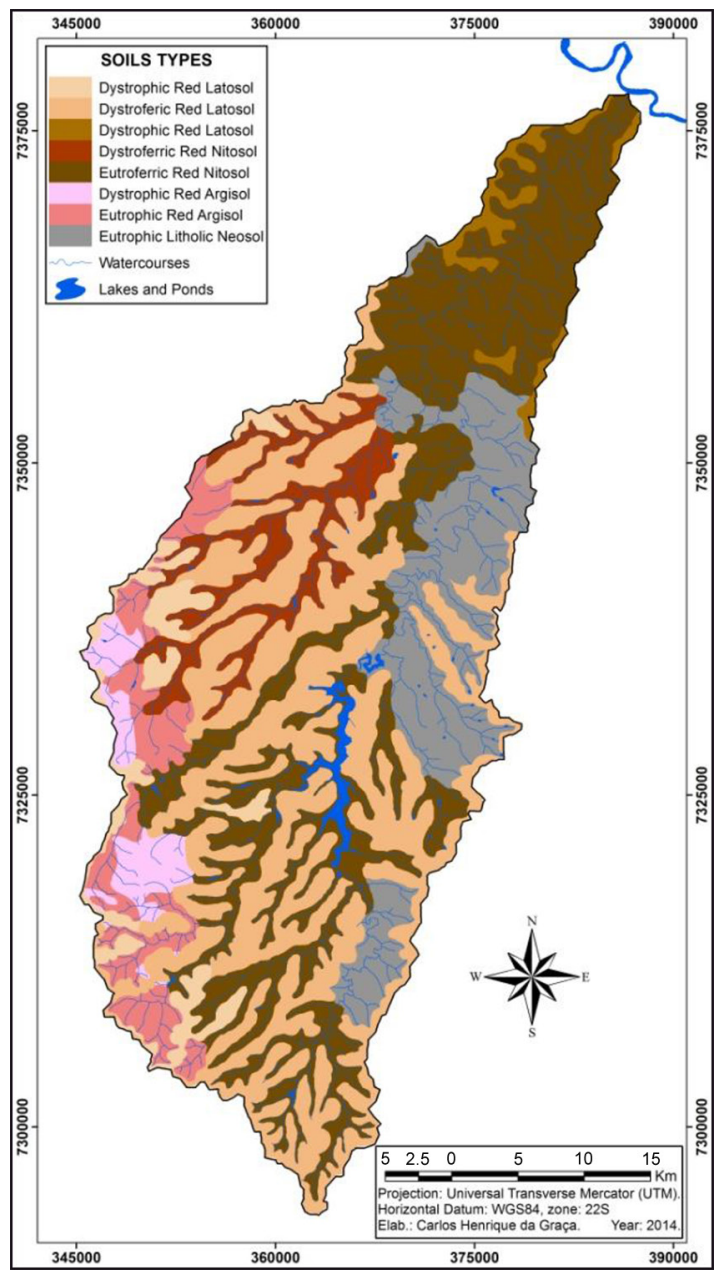

Figure 4. Soil distribution in the hydrographic basin of the river Mourão, state of Paraná - Brazil.

Nitosols, followed by LitholicNeosols come next (Table 2). They are less developed soils and generally occur between the average and low slope (Figure 4) associated to steeper declivities. Lastly, there are the Argisols (Table 2) with high degree of erodibility. They are developed soils with an accumulation of clay (Bt), generally with an abrupt transition and high textural gradient (EMBRAPA, 2013) found at different positions on the slope (Figure 4).

The topographic factor (LS) for the basin had high indexes $(>20)$. However, rates less than 1 were predominant. A significant number of rates between 1 and 5 was also extant (Figure 5). Very close indexes were also reported by Tomazoni et al. (2005) and Stipp et al. (2011) in small basins with similar characteristics.

Vegetal cover and land use in the watershed did not reveal very significant variations with regard to the cultivated area and types of main usage during the years under analysis. The progressive increase of temporary crops plantations (sugar cane, soybean, corn and wheat) and the significant decrease of pasture land, especially between 1993 and 2003, with a 48\% reduction in area, should be

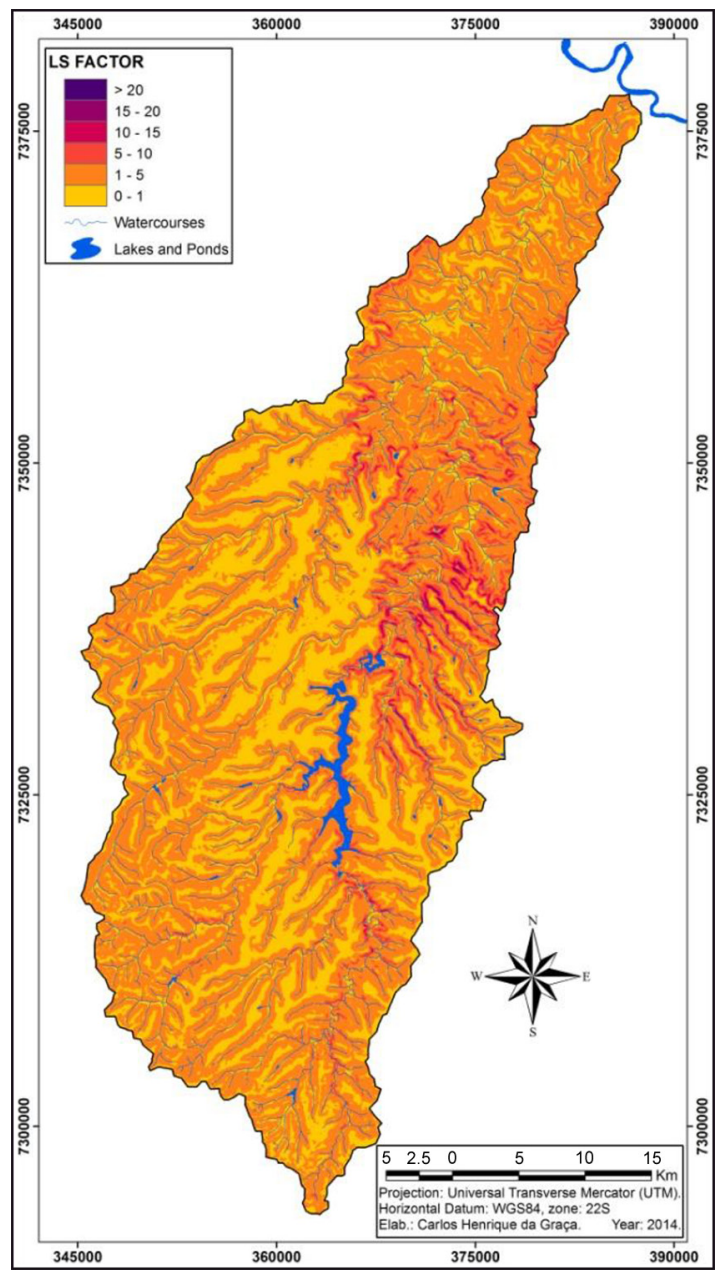

Figure 5. Distribution of indexes of the topographical factor for the river Mourão watershed, state of Paraná - Brazil.

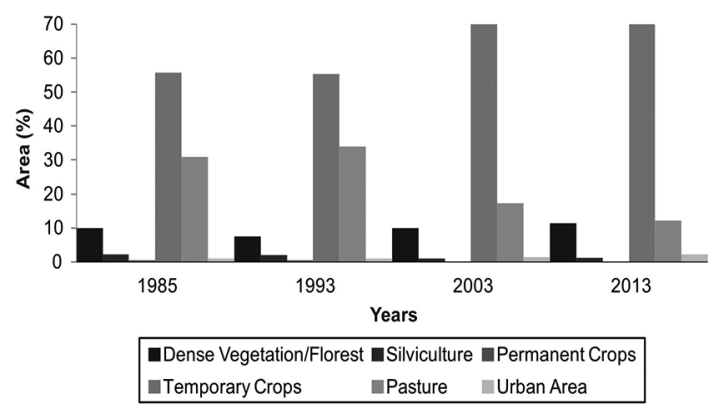

Figure 6. Percentages in vegetal/forest cover of land in the hydrographic basin of the river Mourão, state of Paraná - Brazil.

underpinned (Figure 6). Further, the recovery of natural vegetation areas in the region which had a $51 \%$ expansion between 1993 and 2013 was a positive factor (Figure 6). Other types of usages had a lower than 5\% indexes in all the years analyzed.

As a rule, the river Mourão watershed features a type of land use distribution limited by land relief during the 


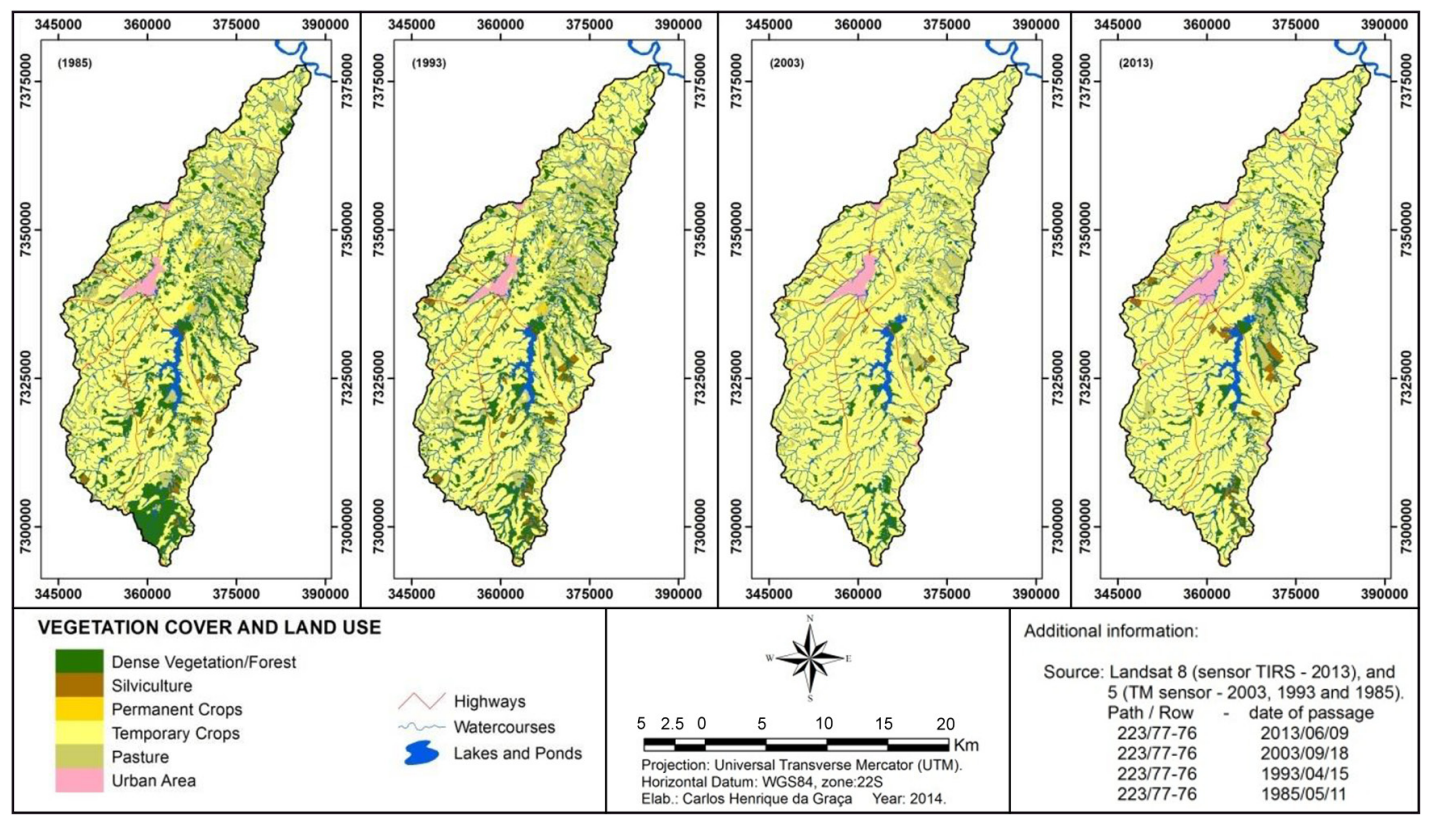

Figure 7. Distribution of vegetal/forest classes and land use in the hydrographic basin of the river Mourão, state of Paraná - Brazil.

years under analysis, with the more effective occurrence of temporary crops in the northern and in the center-southern region of the basin (Figure 7) where land relief is more appropriate. On the other hand, pastures are largely found in the basin's center-western region (Figure 7), a region with more broken features. Other uses do not depend on the land relief even though areas with preserved vegetation are more common near streams and slopes (Figure 7).

Factor $\mathrm{C}$ rates were based on uses identified in the basin and characterized by the protection degree provided to the soil (Table 3). The lower the index applied, the more efficient is the protection; the higher the index, the higher the care to be provided. The same association has been undertaken to attribute rates for factor P (Table 3). The main conservationist practice in the hydrographic basin is directly related to contour plantations in agricultural areas and hedging in pasturelands.

The Natural Potential to Surface Erosion (NPE) was assessed and classified by USLE data. NPE was established by the correlation of its natural factors, or rather, erosivity $(\mathrm{R})$, erodibility (K) and topography (LS) (Pedro and Lorandi, 2004). Although very high NPE indexes were reported for the hydrographic basin, over 750 ton. $\mathrm{ha}^{-1}$.year ${ }^{-1}$ (Figure 8), low to very low NPE rates predominated, with approximately $90 \%$ of the basin's area. The areas mainly lie on Latosols and Nitosols (Figure 4) within a top and average slope topographic situation, with a lower than $8 \%$ declivity. However, the main NPE conditioning factor is the topography with great similarity to its spatialization $\left(\mathrm{r}^{2}=0.97\right)$ and different from that given for soils $\left(\mathrm{r}^{2}=0.08\right)$. The above data agrees with that one provided by Alvares and Silva (2005). Erosivity correlation could not be established due to annualvariability.

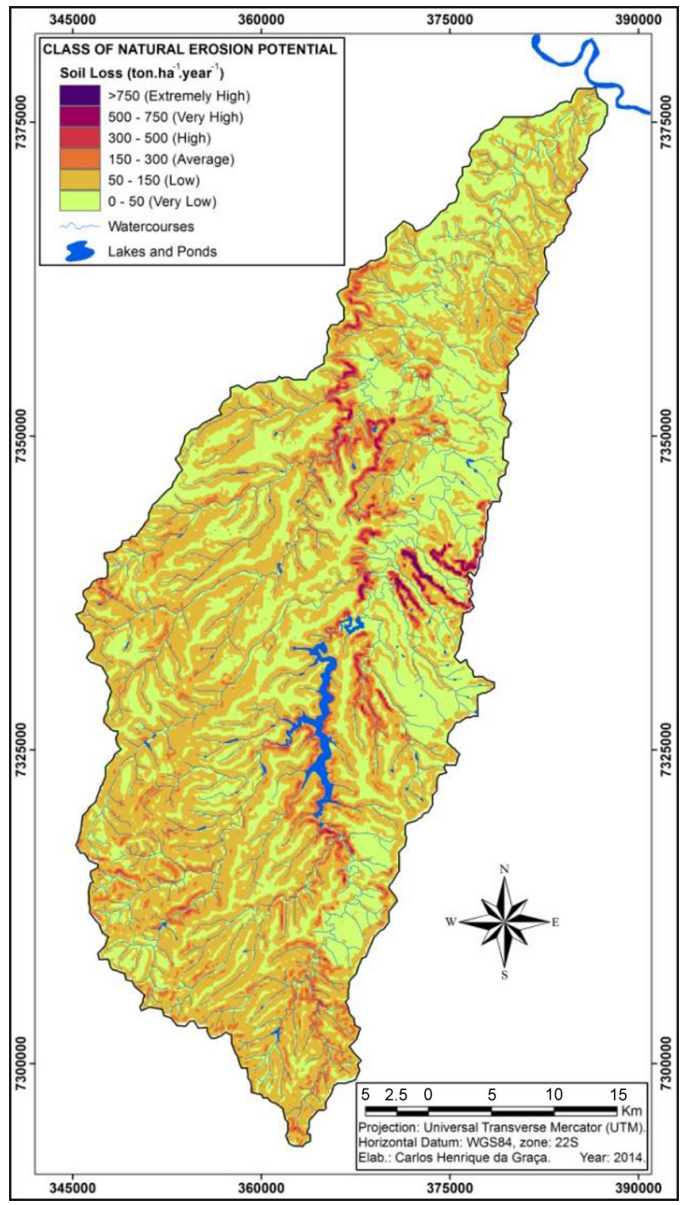

Figure 8. Classes of Natural Potential to Surface Erosion (NPE) for the river Mourão watershed, state of Paraná - Brazil. 
Table 3. Index of factors $C$ and $P$ attributed to classes of vegetal cover and land usage in the river Mourão watershed, state of Paraná - Brazil.

\begin{tabular}{llc}
\hline \multicolumn{1}{c}{$\begin{array}{c}\text { Vegetation Cover and } \\
\text { Land Use }\end{array}$} & $\begin{array}{c}\text { Factor } \\
(\mathbf{C})\end{array}$ & $\begin{array}{c}\text { Factor } \\
(\mathbf{P})\end{array}$ \\
\hline Dense Vegetation/Florest & $0.001^{1}$ & $0.1^{1}$ \\
Silviculture (Eucalypt) & $0.0489^{2}$ & $0.2^{1}$ \\
Permanent Crops (Coffee) & $0.135^{3}$ & $0.5^{1}$ \\
Temporary Crops (sugar cane, & $0.5^{1}$ & $0.5^{1}$ \\
soybeans, corn and wheat) & & \\
Pasture & $0.01^{1}$ & $0.4^{1}$ \\
Urban Area & $1.0^{4}$ & $1.0^{1}$ \\
\hline
\end{tabular}

Souce: Factor C: ${ }^{1}$ Tomazoni and Guimarães (2005). ${ }^{2}$ Oliveira et al. (2007). ${ }^{3}$ Vázquez-Fernández et al. (1996); ${ }^{4}$ Vitte (1997). Factor P: ${ }^{\prime}$ Bertoni and Lombardi Neto (2005).

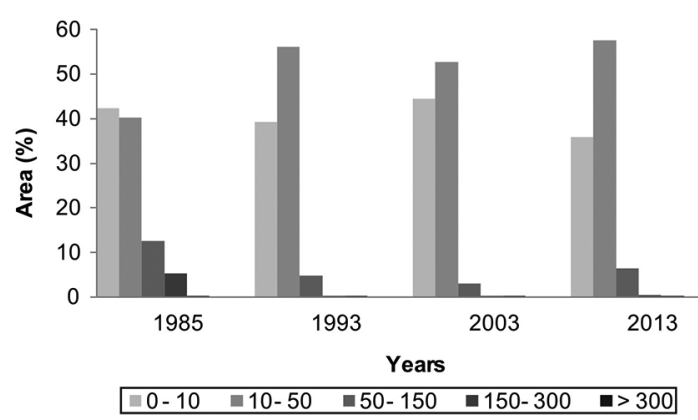

Figure 9. Estimated annual percentage of soil loss for the river Mourão watershed, state of Paraná - Brazil.
NPE helped establish a correlative standard of soil loss according to multi temporal analysis. In other words, it was possible not only to estimate but also to measure whether practices and uses adopted were intensifying or decreasing annual soil loss, when anthropic factors were added to the equation (USLE).

During the years under analysis, there was a decrease in the highest soil loss rates when compared to NPE, with a predominance of indexes lower than 50 ton.ha ${ }^{-1}$.year ${ }^{-1}$ (Figure 9), agreeing with results found by Tomazoni and Guimarães (2005), Tomazoni et al. (2005), Stipp et al. (2011) and Souza and Gasparetto (2012). The above reveals a balance in soil loss even with alternations in usage types of the basin throughout the years.

The greatest concentration in rates over 50 ton.ha ${ }^{-1}$.year ${ }^{-1}$ occurred in 1985, followed by 2013 (Figure 9). The gradual decrease of rates between 1993 and 2003 occurred which, when summed every year, did not exceed $5 \%$ of the basin's area (Figure 9).

Soil loss during the years analyzed did not reveal any significant distinctions with regard to distribution standards. Intensifications occurred in certain sectors, namely in the central-eastern and south-western parts of the watershed (Figure 10). The above may be associated with changes in usage types with an enlargement of temporary crops replacing extensive pastureland. This practice intensified soil exposure to erosion by rain precisely in the areas where more erosion-sensitive soils (Argisol and LitholicNeosol) were predominant.

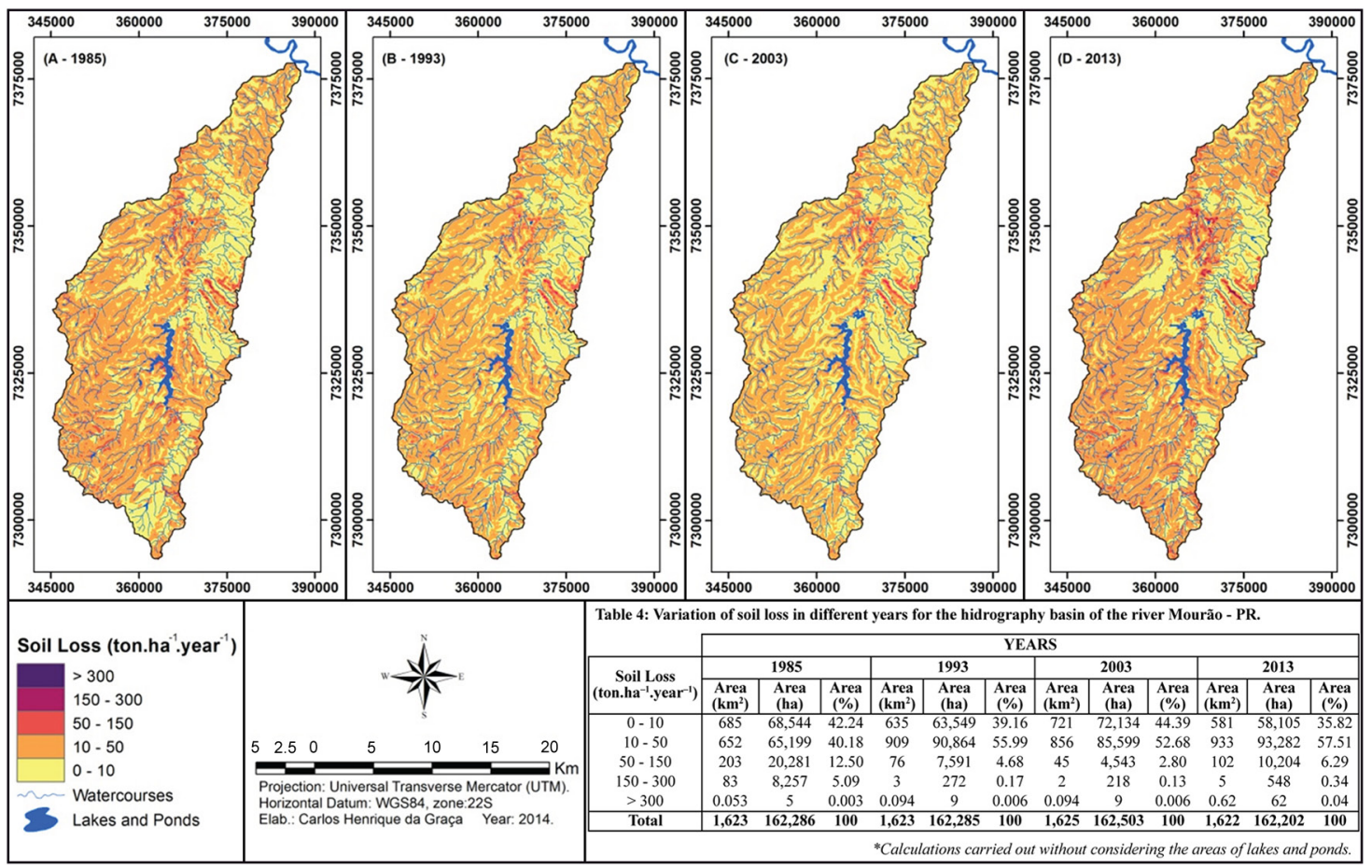

Figure 10. Multi temporal variation of estimated annual soil loss in the river Mourão hydrographic basin, state of Paraná, Brazil: A) 1985; B) 1993; C) 2005; D) 2013. 
Current analysis provided a good response with regard to survey and data crossing in SIG environment, although results of multi temporal soil loss for the watershed failed to demonstrate significant variations that would strengthen this specific type of analysis. However, the factors discussed may be a help in a better exploitation of cultivatable areas and improve the use of more erosion-vulnerable areas to avoid significant erosion-caused loss of soil.

\section{Acknowledgements}

The authors would like to thank the Brazilian Council for Scientific and Technological Development (CNPq) for the scholarship awarded; to FINEP and to the members of the project titled Monitoring of the Urban and Rural Hydrographic Basins - Analysis of water quality and socio-economical aspects: River Mourão hydrographic basin.

\section{References}

ALBUQUERQUE, A.W., CHAVES, I.B. and VASQUES FILHO, J., 1994. Características físicas da chuva correlacionadas com as perdas de solo num regolitoeutrófico de Caruaru (PE). Revista Brasileira de Ciências do Solo, vol. 18, pp. 279-283.

ALVARES, C.A. and SILVA, A.M., 2005. Características das vertentes e potencial natural de erosão da bacia hidrográfica do Ribeirão dos Pinheirinhos (Torrinha/Brotas - SP). In: Anais do XI Simpósio Brasileiro de Geografia Física Aplicada, 2005, São Paulo. São Paulo: USP. 11 p.

ANDRADE, A.C., LEAL, L.R., GUIMARÃES, R.F., CARVALHO JUNIOR, O.A., MARTINS, E.S. and REATTO, A., 2002. Estudo dos processos erosivos na Bacia do Rio Grande (BA) como subsídio ao planejamento agroecológico. Boletim de Pesquisa e Desenvolvimento / Embrapa Amazonia Oriental, vol. 63, pp. 1-26.

ANDRADE, A.R. and NERY, J.T., 2002. Análise da precipitação pluviométrica da bacia hidrográfica do rio Ivaí. In: Anais do Congresso Brasileiro de Meteorologia, 2002, Foz do Iguaçu. Foz do Iguaçu: Sociedade Brasileira de Meteorologia.

BALDO, M.C., 2006. Variabilidade pluviométrica e a dinâmica atmosférica na bacia hidrográfica do rio Ivaí - PR. Presidente Prudente: Universidade Estadual Paulista, 172 p. PhD Thesis.

BERTONI, J. and LOMBARDI NETO, F., 2005. Conservação do solo. 5th ed. São Paulo: Ícone. 355 p.

BIGARELLA, J.J. and MAZUCHOWSKI, J.Z., 1985. Visão integrada da problemática da erosão. Curitiba: ADEA, ABGE. 332 p.

BUENO, C.R.P., 1994. Zoneamento da suscetibilidade à erosão dos solos da Alta e Média Bacia do Rio Jacaré-Pepira, com vistas ao planejamento ambiental. Rio Claro: Universidade Estadual Paulista. 137 p. PhD Thesis.

BURIN, R.H., 1999. Avaliação temporal de perdas de solo na Bacia Hidrográfica do Ribeirão Preto (SP) utilizando geoprocessamento. Piracicaba: Universidade Estadual Paulista, 135 p. Masters Dissertation.

CARAMORI, P.H., GONÇALVES, S.L. and FARIA, R.T.F., 2003. Zoneamento agrícola do Estado do Paraná. Londrina: IAPAR. 76 p.
CARVALHO JUNIOR, O.A. and GUIMARÃES, R.F., 2001. Implementação em ambiente computacional e análise do emprego da área de contribuição no cálculo do fator topográfico (LS) da USLE. In: Anais do VII Simpósio Nacional de Controle de Erosão, 2001, Goiânia. Goiânia: Universidade Federal de Goiás.

CARVALHO, N.O., 2008. Hidrossedimentologia prática. 2nd ed. Rio de Janeiro: Interciência. $602 \mathrm{p}$

CASTRO, A.G. and VALÉRIO FILHO, M., 1997. Simulação da expectativa de perdas de solo em microbacia sob diferentes manejos florestais. Revista Brasileira de Ciências do Solo, vol. 21, no. 1, pp. 419-426. http://dx.doi.org/10.1590/S0100-06831997000300010.

CATÂNEO, A., CARVALHO, G.M.B.S., VASQUES FILHO, J. and LOMBARDI NETO, F., 1992. Correlação entre o índice de erosividade EI30 médio mensal e o coeficiente de chuva do município de Mococa - SP. Científica, vol. 19, no. 1, pp. 1-7.

CAVIGLIONE, J.H., KIIHL, L.R.B., CARAMORI, P.H. and OLIVEIRA, D., 2000. Cartas climáticas do Paraná. Londrina: IAPAR. CD-ROM.

CERRI, C.E.P., 1999. Mapeamento das áreas de risco de erosão dos solos da Bacia do Rio Piracicaba, utilizando geoprocessamento. Piracicaba: Universidade de São Paulo, 89 p. Masters Dissertation.

DENARDIN, J.E., 1990. Erodibilidade do solo estimada por meio de parâmetros físicos e químicos. Piracicaba: Universidade de São Paulo, 110 p. PhD Thesis.

DESMET, P.J.J. and GOVERS, G.A., 1996. GIS procedure for automatically calculating the USLE LS factor on topographically complex landscape units. Journal of Soil and Water Conservation, vol. 51 , no. 5 , pp. 427-433.

EMPRESA BRASILEIRA DE PESQUISA AGROPECUÁRIA - EMBRAPA, 2007. Mapa de Solos do Estado do Paraná. Rio de Janeiro: Embrapa Solos e Florestas. 95 p.

EMPRESA BRASILEIRA DE PESQUISA AGROPECUÁRIA - EMBRAPA, 2013. Sistema Brasileiro de Classificação de Solos. 3rd ed. Brasília: Embrapa Produção de Informação. 353 p.

GALERANI, C., RAMOS, C.L., CHAVES, E., GENZ, F. and BIDONE, F., 1995. Controle da erosão urbana. In: C.E.M. TUCCI, R.L.L. PORTO and M.T. BARROS, orgs. Drenagem urbana. Porto Alegre: ABRH, Editora da UFRGS, pp. 349-387.

GASPARI, F.J., RODRÍGUEZ VAGARÍA, A.V. and SENISTERRA, G.E., 2009. Estimation of soil erosionability in the stream basin of Pillahuinco Grande, Buenos Aires province, Argentina. Ciencia e Investigación Agraria, vol. 35, no. 1, pp. 43-52.

GITAS, I.Z., DOUROS, K., MINAKOU, C., SILlEOS, G.N. and KARYDAS, C.G. 2009. Multi-temporal soil erosion risk assessment in N. Chalkidiki using a modified usle raster model. EARSeL eProceedings, vol. 8, pp. 40-52.

GOLDMAN, S.J., JACKSON, K. and BURSZTYNSKY, T.A., 1986. Erosion and sediment control handbook. New York: McGraw-Hill. 454 p.

GUERRA, A J.T. and ALMEIDA, F.G., 1993. Propriedades dos solos e análises dos processos erosivos no município de Sorriso - MT. In: Anais do IV Encontro Nacional de Estudos Sobre o Meio Ambiente, 1993, Cuiabá. Cuiabá: Instituto de Ciências Humanas e Sociais, Universidade Federal de Mato Grosso, vol. 1, pp. 185-193.

GUERRA, A.J.T., 2010. O início do processo erosivo. In: A.J.T. GUERRA, A.S. SILVA and R.G.M. BOTTELHO, orgs. Erosão 
e conservação dos solos: conceitos, temas e aplicações. 6th ed. Rio de Janeiro: Bertrand do Brasil, pp. 17-50.

INSTITUTO DAS ÁGUAS DO PARANÁ, 2014 [viewed 2005 May 2014]. Sistema de Informações Hidrológicas [online]. Available from: http://www.aguasparana.pr.gov.br/

INSTITUTO DE PESQUISAS ESPACIAIS - INPE, 2011 [viewed 22 June 2013]. Projeto TOPODATA [online]. São José dos Campos. Available from: http://www.dsr.inpe.br/topodata/

KÖPPEN, W., 1948. Climatologia: com um estudio de los climas de latierra. In: INSTITUTO AGRONÔMICO DO PARANÁ - IAPAR. Cartas climáticas básicas do Estado do Paraná. Londrina. 41 p.

LOMBARDI NETO, F. and BERTONI, J., 1975. Erodibilidade de solos paulistas. Campinas: Instituto Agronômico de Campinas. 12 p. Boletim Técnico, no. 28.

LOMBARDI NETO, F. and MOLDENHAUER, W.C., 1992. Erosividade da chuva: sua distribuição e relação com as perdas de solo em Campinas (SP). Bragantina, vol. 51, no. 2, pp. 189-196.

LOMBARDI NETO, F., 1994. Erodibilidade de solos do Estado de São Paulo avaliada por atributos físicos e químicos. In: Anais da X Reunião Brasileira de Manejo e Conservação do Solo e da Água, 1994, Florianópolis. Florianópolis: Universidade Federal de Santa Catarina.

LONGLEY, P.A., GOODCHILD, M.F. and MAGUIRE, D.J. and RHIND, D.W., 2013. Sistemas e ciência da informação geográfica. 3rd ed. Porto Alegre: Bookmam. 540 p.

LOPES, V.L., 1980. Um estudo da erosão e produção de sedimentos pelas chuvas. Mossoró: Escola Superior de Agricultura de Mossoró. 71 p.

MARCONDES, D.A.S., VEIGA, R.A.A., CARVALHO, C.M., SAID, L.A. and CHAIN, M.G., 2002. Controle de erosão e assoreamento na área de influência do reservatório da UHE Eng. Sérgio Motta: planejamento ambiental: microbacia do Ribeirão Caiuá. São Paulo: Companhia Energética de São Paulo. 85 p. Série Divulgação e Informação, no. 248.

MORETI, D., CARVALHO, M.P., MANNIGEL, A.R. and MEDEIROS, L.S., 2003. Importantes características de chuva para a conservação do solo e da água no município de São Manoel (SP). Revista Brasileira de Ciencia do Solo, vol. 1, no. 1, pp. 713-726. http://dx.doi.org/10.1590/S0100-06832003000400016.

OLIVEIRA, A.M.M., PINTO, S.A.F. and LOMBARDI NETO, F., 2007. Caracterização de indicadores da erosão do solo em bacias hidrográficas com o suporte de geotecnologias e modelo predictivo. Estudos Geográficos, vol. 5, no. 1, pp. 63-86.

PAES, F.S., DUPAS, F.A., SILVA, F.G.B. and PEREIRA, J.C.D., 2010. Spatialization of soil loss in the basins that compose the city of Santa Rita do Sapucaí - MG (Brazil). Geociências, vol. 29 , no. 4 , pp. 589-601.

PARANÁ. Secretaria do Estado da Agricultura e do Abastecimento. Instituto de Terras, Cartografia e Florestas, 1987. Atlas do Estado do Paraná. Curitiba. 73 p.

PEDRO, F.G. and LORANDI, R., 2004. Potencial natural de erosão na área periurbana de São Carlos - SP. Revista Brasileira de Cartografia, vol. 56, no. 1, pp. 28-33.

PRADO, J.P.B. and NÓBREGA, M.T., 2005. Determinação de perdas de solo na bacia hidrográfica do córrego Ipiranga em Cidade Gaúcha, Estado do Paraná, com aplicação da Equação Universal de Perdas de Solo (EUPS). Acta Scientiarum Technology, vol. 27 , no. 1 , pp. 33-42.
PRIMAVESI, A., 1988. Manejo ecológico dos solos em regiões tropicais. São Paulo: Nobel. 549 p.

RAMOS, C.L., 1995. Erosão urbana e produção de sedimentos. C.E.M. TUCCI, R L.L. PORTO and M.T. BARROS, orgs. Drenagem urbana. Porto Alegre: ABRH, Editora da UFRGS, pp. 241-277.

RANIERI, S.B.L., SPAROVEK, G., SOUZA, M.P. and DOURADO NETO, D., 1998. Aplicação de índice comparativo na avaliação do risco de degradação das terras. Revista Brasileira de Ciência do Solo, vol. 22, no. 4, pp. 751-760.

RESENDE, M., and ALMEIDA, J.R., 1985. Modelos de predição de perdas de solo: uma ferramenta para manejo e conservação do solo. Informe Agropecuário, vol. 11, no. 128, pp. 38-53.

RODRIGUES, J.E., 1984. Estudo geotécnico de fenômenos erosivos acelerados: boçorocas. São Carlos: Universidade de São Paulo. 162 p. PhD Thesis.

ROUSSEVA, S., 2003. Ideas for physical interpretation of the USLE. Trieste: Poushkarov Research Institute for Soil Science and Agroecology, College on Soil Physics, vol. 3, no. 21, pp. 310-319.

RUFINO, R.L. and BISCAIA, R.C.M. and MERTEN, G.H., 1993. Determinação do potencial erosivo da chuva do estado do Paraná, através de pluviometria: terceira aproximação. Revista Brasileira de Ciencia do Solo, vol. 17, pp. 439-444.

RUFINO, R.L., 1986. Avaliação do potencial erosivo da chuva para o estado do Paraná: segunda aproximação. Revista Brasileira de Ciência do Solo, vol. 10, pp. 279-281.

SANTOS, L.J.C., FIORI, C.O., CANALI, N.E., FIORI, A.P., SILVEIRA, C.T., SILVA, J.M.F. and ROSS, J.S., 2006. Mapeamento geomorfológico do Estado do Paraná. Revista Brasileira de Geomorfologia, vol. 7, pp. 3-12.

SERVIÇO GEOLÓGICO DO PARANÁ - MINEROPAR, 2001. Atlas geológico do Estado do Paraná. Curitiba. 125 p. CD-ROM.

SILVA, A.M. and ALVARES, C.A., 2005. Erodibilidade dos solos paulistas: levantamento de informações e estruturação de um banco de dados. Geociências, vol. 24, pp. 33-42.

SILVA, A.M. and SCHULZ, H.E., 2002. Redução do desprendimento das partículas do solo mediante uso de resíduos vegetais de origem urbana. Revista Brasileira de Engenharia Agrícola e Ambiental, vol. 6, no. 3, pp. 531-534. http://dx.doi.org/10.1590/ S1415-43662002000300026.

SILVA, A.M., 1999. Aplicações de geoprocessamento no estudo das relações entre os processos erosivos e sedimentológicos de bacia hidrográfica. São Carlos: Universidade de São Paulo, 249 p. PhD Thesis.

SILVA, A.M., SCHULZ, H.E. and CAMARGO, P.B., 2003. Erosão e hidrossedimentologia em bacias hidrográficas. São Carlos: Rima. 138 p.

SOUZA, V. and GASPARETTO, N.V.L., 2012. Aplicação da Equação Universal de Perdas de Solo (EUPS) na bacia do córrego Pinhalzinho Segundo, noroeste do Paraná. Revista Brasileira de Geomorfologia, vol. 13, pp. 267-278.

STIPP, N.S.F., MENDONÇA, F.A. and CAMPOS, R.A., 2011. O potencial de erosão de uma bacia hidrográfica: utilização da Equação Universal de Perda de Solos (EUPS) como ferramenta de gestão ambiental. Geografia, v. 20, no. 2, pp. 29-51.

TOMAZONI, J.C. and GUIMARÃES, E., 2005. A sistematização dos fatores da EUPS em SIG para quantificação da erosão laminar 
na bacia do rio Jirau. Revista Brasileira de Cartografia, no. 57, pp. 235-244.

TOMAZONI, J.C., MONTOVANI, L.E., BITTENCOURT, A.V.L. and ROSA FILHO, E.F., 2005. A sistematização dos fatores da EUPS em SIG para quantificação da erosão laminar na bacia do rio Anta Gorda (PR). Estudos Geográficos, vol. 3, no. 1, pp. 1-21.

U.S. GEOLOGICAL SURVEY - USGS-GLOVIS, 2013 [viewed 10 October 2013]. Imagens de Satélite Landsat [online]. Washington. Available from: http://glovis.usgs.gov/

VALÉRIO FILHO, M., 1994. Técnicas de geoprocessamento e sensoriamento remoto aplicado ao estudo integrado de bacias hidrográficas. In: V.P. PEREIRA, M.V. FERREIRA and M.C.P. CRUZ, eds. Solos altamente suscetiveis à erosão. Jaboticabal: Faculdade de Ciências Agrárias e Veterinárias, Universidade Estadual Paulista, Sociedade Brasileira de Ciências do Solo, pp. 223-242.

VÁZQUEZ-FERNÁNDEZ, G.A., FORMAGGIO, A.R., EPIPHANIO, J.C.N. and GLERIANI, J.M., 1996. Determinação de seqüências culturais em microbacia hidrográfica para caracterização do Fator C da EUPS, utilizando fotografia aérea. In: Anais do VIII Simpósio Brasileiro de Sensoriamento Remoto, 1996, Salvador. São José dos Campos: INPE, pp. 63-67.
VITTE, A.C., 1997. Metodologia para cálculo de perdas de solo em bacias de drenagem. Boletim Paranaense de Geociências, no. 45 , pp. 59-65.

WALTRICK, P.C., MACHADO, M.A.M., OLIVEIRA, D., GRIMM, A.M. and DIECKOW, J., 2011. Erosividade de chuvas no Estado do Paraná: atualização e influência do "El Niño" $e$ "La Niña”. Curitiba: Sociedade Brasileira de Ciência do Solo, Núcleo Estadual do Paraná. 38 p. Boletim Técnico.

WISCHMEIER, W.H. and SMITH, D.D., 1978. Predicting rainfall erosion losses a guide to conservation planning. Washington: U.S. Department of Agriculture. Agriculture Handbook, no. 537.

ZEVENBERGEN, L.W. and THORNE, C.R., 1987. Quantitative analysis of land surface topography. Earth Surface Processes and Landforms, vol. 12, no. 1, pp. 47-56. http://dx.doi.org/10.1002/ esp.3290120107.

ZHANG, Y., DEGROOTE, J., WOLTER, C. and SUGUMARAN, R., 2009. Integration of Modified Universal Soil Loss Equation (MUSLE) into a GIS framework to assess soil erosion risk. Land Degradation \& Development, vol. 20, no. 1, pp. 84-91. http:// dx.doi.org/10.1002/1dr.893 . 